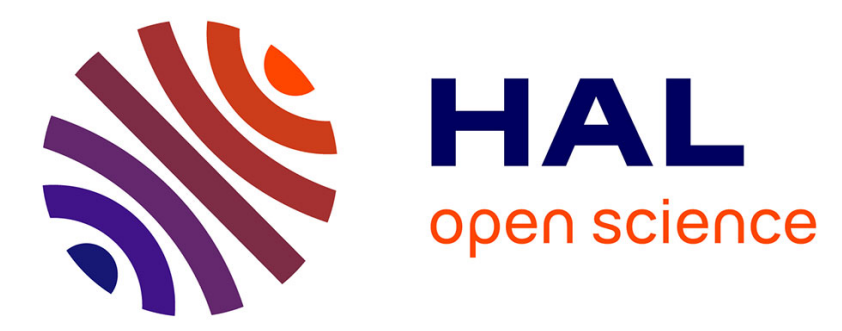

\title{
Nitrogen mineralization peaks under closed canopy during the natural forest development cycle of an old-growth temperate spruce forest
}

Claudia Bade, Mascha Jacob, Hermann F. Jungkunst, Christoph Leuschner, Markus Hauck

\section{To cite this version:}

Claudia Bade, Mascha Jacob, Hermann F. Jungkunst, Christoph Leuschner, Markus Hauck. Nitrogen mineralization peaks under closed canopy during the natural forest development cycle of an old-growth temperate spruce forest. Annals of Forest Science, 2015, 72 (1), pp.67-76. 10.1007/s13595-014-03940 . hal-01284154

\section{HAL Id: hal-01284154 \\ https://hal.science/hal-01284154}

Submitted on 7 Mar 2016

HAL is a multi-disciplinary open access archive for the deposit and dissemination of scientific research documents, whether they are published or not. The documents may come from teaching and research institutions in France or abroad, or from public or private research centers.
L'archive ouverte pluridisciplinaire HAL, est destinée au dépôt et à la diffusion de documents scientifiques de niveau recherche, publiés ou non, émanant des établissements d'enseignement et de recherche français ou étrangers, des laboratoires publics ou privés. 


\title{
Nitrogen mineralization peaks under closed canopy during the natural forest development cycle of an old-growth temperate spruce forest
}

\author{
Claudia Bade - Mascha Jacob • Hermann F. Jungkunst • \\ Christoph Leuschner • Markus Hauck
}

Received: 23 October 2013 / Accepted: 5 June 2014 /Published online: 2 July 2014

(C) INRA and Springer-Verlag France 2014

\begin{abstract}
- Context Old-growth forests with natural forest development and complex stand structure have become extremely rare in Central Europe. Changes of biogeochemistry and the $\mathrm{N}$ cycle across a full forest development cycle are not well understood.

- Aims We tested the hypothesis that net $\mathrm{N}$ mineralization and the relative importance of nitrification are increasing with proceeding forest development from regeneration to decay stages.

- Methods In an unmanaged old-growth spruce forest, we measured net ammonification and nitrification rate in the five forest development stages in 2 years using the intact soil core incubation method.

- Results Net N mineralization (and ammonification) rates were higher in the closed stands of the optimum and overmature stages than in the more open decay and regeneration stages. Only a small proportion of $\mathrm{NH}_{4}{ }^{+}$was oxidized to $\mathrm{NO}_{3}{ }^{-}$ in the studied acidic soils.

- Conclusion Lower $\mathrm{N}$ mineralization in the more open than the closed patches of this natural forest is unexpected, contrasting with the findings from artificial gaps. Possible reasons
\end{abstract}

\section{Handling Editor: Erwin Dreyer}

Contribution of the co-authors $\mathrm{MH}$ and $\mathrm{CL}$ designed the study, $\mathrm{CB}$ conducted the field and laboratory work, MJ, MH, HFJ supervised the work, MJ coordinated the research project, $\mathrm{CB}, \mathrm{MJ}, \mathrm{HFJ}, \mathrm{CL}$ and $\mathrm{MH}$ wrote the paper.

C. Bade $\cdot$ M. Jacob $(\square) \cdot$ C. Leuschner $\cdot$ M. Hauck

Plant Ecology, Albrecht von Haller Institute for Plant Sciences,

University of Göttingen, Untere Karspüle 2, 37073 Göttingen,

Germany

e-mail: mjacob@gwdg.de

\section{H. F. Jungkunst}

Geoecology and Physical Geography, Institute for Environmental Sciences, University of Koblenz-Landau, Fortstraße 7,

76829 Landau, Germany are reduced litter supply and lower canopy $\mathrm{N}$ interception in gaps in this forest under exposure to high $\mathrm{N}$ deposition. Further studies in other old-growth forests are needed to better understand the mechanisms causing long-term change in $\mathrm{N}$ cycling with forest development.

- Key message Nitrogen mineralization was higher in the optimum and over-mature stages with closed canopy than in the more open decay and regeneration stages of an unmanaged old-growth forest with high atmospheric nitrogen load, in contrast to published experiments with artificial gaps.

Keywords Nitrogen cycle $\cdot$ Nitrification $\cdot$ Ammonification . Old-growth forest · Picea abies · Gaps

\section{Introduction}

Ammonification and nitrification are major nitrogen $(\mathrm{N})$ transformation processes in soils providing readily available ammonium $\left(\mathrm{NH}_{4}{ }^{+}\right)$and nitrate $\left(\mathrm{NO}_{3}{ }^{-}\right)$for plant uptake. Both pathways of $\mathrm{N}$ supply depend on abiotic (soil temperature, moisture, and chemistry) and biotic factors (litter chemistry and decomposer activity) but are also influenced by vegetation structure and plant productivity through canopy openness and the amount of litter mass (Prescott 2002). Several studies reported higher $\mathrm{N}$ mineralization rates in gaps than in the forest interior due to higher soil temperatures and higher soil moisture as a consequence of reduced transpiration (e.g., Prescott 2002; Bagherzadeh et al. 2008); however, others found no difference or lower rates in the gap (e.g., Bauhus et al. 2004). The $\mathrm{NO}_{3}{ }^{-} / \mathrm{NH}_{4}{ }^{+}$ratio of $\mathrm{N}$ supply was often higher in the soil of coniferous forest gaps than in the forest interior (Hart et al. 1994; Prescott et al. 2003) due to reduced litter mass and thus lower $\mathrm{C}$ availability in the gap (Hart et al. 1994). The gap effect on soil N supply is relevant for managed forests because mineral $\mathrm{N}$ availability may vary with 
management intensity in clear-cutting, shelterwood, or selective cutting regimes (Schmidt et al. 1996). Much less is known about variation in $\mathrm{N}$ supply with natural gap dynamics in unmanaged old-growth forests, particularly in the decay stage with open canopies and abundant deadwood influencing $\mathrm{N}$ mineralization and nitrification.

As most temperate natural forests have cyclic successional age dynamics forming different forest development stages (Korpel 1995; Stöcker 1997), this natural forest dynamics creates a structurally heterogeneous vegetation pattern with coexistence of dense and open patches (Stöcker 2002) and contrasting microclimatic conditions in the different development stages. Further, the amount of deadwood as a source of decomposable organic matter varies across the forest development cycle (Harmon 2009; Jacob et al. 2013). Deadwood influences soil $\mathrm{N}$ dynamics by acting as a net $\mathrm{N}$ sink in the initial phase of decay while representing a net $\mathrm{N}$ source in later stages (Laiho and Prescott 2004; Spears et al. 2003). This structural heterogeneity in natural forests may also influence $\mathrm{N}$ mineralization, plant $\mathrm{N}$ uptake and thus the balance between supply and plant demand at the stand level over long time spans.

The productivity of most temperate and boreal forests is limited by low $\mathrm{N}$ availability (Vitousek et al. 1997), and acidic coniferous forests have generally been considered to have a tight $\mathrm{N}$ cycle with almost all mineralized $\mathrm{N}$ taken up by roots (Vestgarden et al. 2004). However, increasing atmospheric $\mathrm{N}$ deposition has reduced the growth limitation of temperate forests by $\mathrm{N}$ in many regions, and at sites with high atmospheric $\mathrm{N}$ input, forest soils can even become saturated with $\mathrm{N}$ (Aber et al. 2003). This factor must be considered when examining the dynamics of $\mathrm{N}$ transformation processes across the natural forest development cycle. The interception of $\mathrm{N}$ and other substances from atmospheric sources increases with the size of the intercepting canopy surface area (Lovett and Lindberg 1993; Hauck and Runge 2002) and thus may increase with tree age and stand density in the early stages of stand development (Rothe and Mellert 2004). Elevated N deposition increases not only the plant available $\mathrm{N}$ pool, but may also lead to increased N mineralization (Peréz et al. 1998) revealing complex interactions between atmospheric and soil $\mathrm{N}$ fluxes.

Norway spruce (Picea abies (L.) H. Karst.) is one of the two economically most important tree species in Central Europe's forestry sector. Many studies have addressed the $\mathrm{N}$ cycle and $\mathrm{N}$ mineralization in planted spruce stands (e.g., Persson and Wirén 1995), but not much is known about $\mathrm{N}$ mineralization in natural old-growth spruce forests, especially in the decay stage. Since over-mature and decaying trees are unique elements of old-growth forests that are lacking in managed forests, we asked how the natural stand development, especially with the presence of over-mature and decay stages might influence net $\mathrm{N}$ mineralization and nitrification.
With a comparative study in all five forest development stages (regeneration to decay) of a natural mountain spruce forest, we tested the hypotheses that (i) the soil in patches with overmature and decaying spruce trees supports higher $\mathrm{N}$ mineralization rates than soil in the younger forest development stages due to more favorable abiotic conditions, and (ii) an increasing proportion of the released $\mathrm{NH}_{4}{ }^{+}$is oxidized to $\mathrm{NO}_{3}{ }^{-}$when canopy closure decreases from early to late stages of the forest development cycle. We further asked whether these expected patterns would persist under chronic $\mathrm{N}$ deposition as is characteristic for most parts of Central Europe and the study region.

\section{Material and methods}

\subsection{Study site}

The study was carried out in the Harz Mountains in Central Germany with Mt. Brocken as the highest peak $(1,142 \mathrm{~m}$ a.s.l.). The study site was chosen in a natural old-growth Norway spruce stand of the Calamagrostio villosaePiceetum community (temperate mountain spruce forests; Dittrich et al. 2013) located on the eastern slope of Mt. Brocken at elevations between 930 and 1,000 $\mathrm{m}$ a.s.l. This forest stand of c. 300 ha in the core protection zone of Harz National Park is one of the last remaining unmanaged oldgrowth forests in Central Europe. Since the early Middle Ages (ca. $800 \mathrm{AD}$ ), the area was reserved as a hunting ground for the nobility and clergy (Schade 1926). The forest was banned from logging and forest pasture and was never exploited for charcoal production during medieval times (Kortzfleisch 2008), a widespread forest use practice in that time. Due to low human influence and the fact that the studied spruce stand has not been used for timber harvesting for several centuries, the stand follows natural stand dynamics from the regeneration through the optimum to the decay stage. A typical cycle is thought to last for about 300 years and is dominated only by spruce (Stöcker 1997). We installed 25 plots of $10 \mathrm{~m} \times 10 \mathrm{~m}$ size in order to cover the whole spectrum of stages of the forest development cycle, considering the five development classes of Stöcker (1997) (Table 1), each being replicated five times. Dendrochronological evidence shows that the oldest trees are more than 280 years old (Hauck et al. 2012). The plots were chosen in a stratified random selection procedure in order to exclude patches with blanket bog formation and shallow Leptosols on boulders. The climate on Mt. Brocken is characterized by an annual mean temperature of $3-3.5^{\circ} \mathrm{C}$, annual precipitation of $1,600 \mathrm{~mm}^{-1} \mathrm{ear}^{-1}, 130$ to 170 days with snow cover, and more than 300 fog days (Glässer 1994). The bedrock is granite and the dominant soil type Stagnic Cambisol (IUSS Working Group WRB 2006). Soils were highly acidic and strongly affected by slope water and locally 
Table 1 Structural attributes (based on Stöcker 1997, modified) and stand characteristics of the five forest development stages on Mt. Brocken

\begin{tabular}{|c|c|c|c|c|c|}
\hline & $\begin{array}{l}\text { A } \\
\text { Regeneration }\end{array}$ & $\begin{array}{l}\mathrm{B} \\
\text { Initial }\end{array}$ & $\begin{array}{l}\mathrm{C} \\
\text { Optimum }\end{array}$ & $\begin{array}{l}\text { D } \\
\text { Over-mature }\end{array}$ & $\begin{array}{l}\text { E } \\
\text { Decay }\end{array}$ \\
\hline Number of tree individuals & Low to high, increasing & Very high, decreasing & High, stable & High, decreasing & $\begin{array}{l}\text { Medium to low, } \\
\text { decreasing }\end{array}$ \\
\hline Canopy cover & Low, steadily increasing & $\begin{array}{l}\text { Medium to high, } \\
\text { closure of gaps }\end{array}$ & $\begin{array}{l}\text { High, closure of } \\
\text { gaps }\end{array}$ & $\begin{array}{l}\text { Decreasing, gap } \\
\text { formation }\end{array}$ & $\begin{array}{l}\text { Medium to low, } \\
\text { decreasing }\end{array}$ \\
\hline Tree mortality & Low & Medium & Low & Medium-high & High \\
\hline Deadwood & $\begin{array}{l}\text { Remaining from } \\
\text { decay phase }\end{array}$ & $\begin{array}{l}\text { Small-sized wood } \\
\text { debris }\end{array}$ & Increasing & $\begin{array}{l}\text { Increasing in } \\
\text { canopy layer }\end{array}$ & Dead tress dominate \\
\hline Canopy stratification & $\begin{array}{l}\text { Very few mature } \\
\text { trees and offspring }\end{array}$ & $\begin{array}{l}\text { Heterogeneous } \\
\text { structure }\end{array}$ & $\begin{array}{l}\text { Low variance in tree } \\
\text { height }\end{array}$ & $\begin{array}{l}\text { Low variance in } \\
\text { tree height }\end{array}$ & $\begin{array}{l}\text { Disintegration of } \\
\text { canopy layer }\end{array}$ \\
\hline Tree size, age structure & Saplings dominate & $\begin{array}{l}\text { Medium-sized trees, } \\
\text { low variance }\end{array}$ & $\begin{array}{l}\text { Tall to medium-sized } \\
\text { trees, low variance }\end{array}$ & $\begin{array}{l}\text { Tall trees, low } \\
\text { variance }\end{array}$ & $\begin{array}{l}\text { Tall (dead) trees and } \\
\text { saplings }\end{array}$ \\
\hline Tree vitality & Very high & High & $\begin{array}{l}\text { Stagnating- } \\
\text { decreasing }\end{array}$ & Low & Low, dieback \\
\hline Tree regeneration & Abundant & $\begin{array}{l}\text { Medium-low, } \\
\text { partly suppressed }\end{array}$ & $\begin{array}{l}\text { Very low, } \\
\text { suppressed }\end{array}$ & $\begin{array}{l}\text { Low, partly } \\
\text { suppressed }\end{array}$ & Starting in groups \\
\hline Stem density of live trees $\left(\mathrm{N} \mathrm{ha}^{-1}\right)$ & $40 \pm 40 \mathrm{a}$ & $960 \pm 289 \mathrm{~b}$ & $480 \pm 66 \mathrm{ab}$ & $380 \pm 37 \mathrm{ab}$ & 0 \\
\hline Mean tree height of live trees $(\mathrm{m})$ & $3.2 \mathrm{a}$ & $6.6 \pm 0.2 \mathrm{a}$ & $22.5 \pm 1.4 \mathrm{~b}$ & $22.3 \pm 0.8 \mathrm{~b}$ & - \\
\hline Mean dbh of live trees $(\mathrm{cm})$ & $7.6 \mathrm{a}$ & $12.4 \pm 0.6 \mathrm{a}$ & $43.2 \pm 3.3 \mathrm{~b}$ & $48.6 \pm 1.3 \mathrm{~b}$ & - \\
\hline Total deadwood $\left(\mathrm{m}^{3} \mathrm{ha}^{-1}\right)$ & $351 \pm 101 \mathrm{a}$ & $156 \pm 39 \mathrm{a}$ & $50 \pm 8 \mathrm{a}$ & $242 \pm 89 \mathrm{a}$ & $1,280 \pm 319 b$ \\
\hline \multicolumn{6}{|l|}{ Herb layer $(\text { cover in } \%)^{\mathrm{a}}$} \\
\hline Deschampsia flexuosa & $36 \pm 6 \mathrm{a}$ & $23 \pm 5 \mathrm{a}$ & $39 \pm 6 \mathrm{a}$ & $46 \pm 11 \mathrm{a}$ & $28 \pm 11 \mathrm{a}$ \\
\hline Calamagrostis villosa & $23 \pm 9 \mathrm{a}$ & $21 \pm 6 \mathrm{a}$ & $25 \pm 6 \mathrm{a}$ & $20 \pm 6 \mathrm{a}$ & $41 \pm 8 \mathrm{a}$ \\
\hline Galium saxatile & $21 \pm 12 \mathrm{a}$ & $7.5 \pm 3.7 \mathrm{a}$ & $2.2 \pm 1.8 \mathrm{a}$ & $5.4 \pm 2.7 \mathrm{a}$ & $12 \pm 3 \mathrm{a}$ \\
\hline Vaccinium myrtillus & $12 \pm 8 \mathrm{a}$ & $21 \pm 10 \mathrm{a}$ & $9.3 \pm 4.9 \mathrm{a}$ & $17 \pm 5 \mathrm{a}$ & $9.0 \pm 5.8 \mathrm{a}$ \\
\hline Picea abies & $1.0 \pm 0.4 \mathrm{a}$ & $1.3 \pm 0.8 \mathrm{a}$ & $1.2 \pm 0.9 \mathrm{a}$ & $0.7 \pm 0.2 \mathrm{a}$ & $0.5 \pm 0.1 \mathrm{a}$ \\
\hline
\end{tabular}

Within a row, means sharing the same letter, do not differ significantly $(P<=0.05$, Kruskal-Wallis test)

${ }^{a}$ Dominating herb layer species according to Dittrich et al. (2013)

also by waterlogging. The dominant humus form was morlike moder (Zanella et al. 2011). The mass of standing deadwood differed significantly with highest values in the decay stage (about $200 \mathrm{Mg} \mathrm{C} \mathrm{ha}^{-1}$ ) and lowest values in the optimum stage $\left(2 \mathrm{Mg} \mathrm{Cha}^{-1}\right)$, while the mass of lying deadwood showed no significant differences (Jacob et al. 2013).

\subsection{Measurement of $\mathrm{N}$ mineralization and nitrification rates}

In situ rates of net $\mathrm{N}$ ammonification and net nitrification were determined by the intact soil core incubation technique (Hart et al. 1994) using stainless steel cylinders of $6.5 \mathrm{~cm}$ inner diameter and $40 \mathrm{~cm}$ length with both ends open to rain, drainage, and evaporation. In the mostly shallow soil profiles, we investigated the topsoil $(0-10 \mathrm{~cm})$ (excluding the humus) and the lower 10-20 cm horizon. In 2009, samples were taken at each plot corner (at $3.5 \mathrm{~m}$ distance from the plot corner for avoiding edge effects) and in the center of the 25 plots resulting in five replicate samples per plot, soil depth, and sampling period (500 samples in total: 25 plots $\times 2$ depths $\times 2$ periods $\times 5$ replicates). In 2010, a reduced sampling design was applied with samples collected only in the plot center (only one replicate per plot, soil depth, and sampling period, i.e., 100 samples in total). The cylinders were installed for two 30-day intervals in summer (July/August) and autumn (September/October) of 2009 and 2010, thereby covering most of the short growing season on cool Mt. Brocken (Table 2). A second set of cylinders with soil cores extracted in direct vicinity of the incubated ones was returned to the laboratory immediately after installing the cylinders for determining the inorganic $\mathrm{N}$ stocks at the beginning of the

Table 2 Mean daily temperature and precipitation totals during the four incubation periods in the summers and autumns of 2009 and 2010

\begin{tabular}{llrll}
\hline Year & Season & Temperature $\left({ }^{\circ} \mathrm{C}\right)$ & $\begin{array}{l}\text { Precipitation } \\
\left(\mathrm{mm} \mathrm{day}^{-1}\right)\end{array}$ & $\begin{array}{l}\text { Incubation } \\
\text { period (days) }\end{array}$ \\
\hline 2009 & Summer & $12.4 \pm 0.5$ & $4.3 \pm 1.2$ & 28 \\
& Autumn & $8.2 \pm 0.6$ & $5.1 \pm 1.4$ & 30 \\
2010 & Summer & $15.2 \pm 0.8$ & $1.6 \pm 0.6$ & 28 \\
& Autumn & $6.8 \pm 0.5$ & $5.0 \pm 1.7$ & 41 \\
\hline
\end{tabular}

Calculations are based on daily data of the German National Meteorological Service (Deutscher Wetterdienst, Offenbach, Germany) recorded on top of Mt. Brocken 
incubation. The material was kept cool during the transport (about 3-4 h). In the laboratory, a few drops of chloroform were added for retarding microbial growth, and the soil samples were immediately extracted with $150 \mathrm{ml} 0.5 \mathrm{M} \mathrm{K}_{2} \mathrm{SO}_{4}$ solution using a ratio of soil to $\mathrm{K}_{2} \mathrm{SO}_{4}$ solution of approximately 1:3. The samples were shaken for $1 \mathrm{~h}$, the solution subsequently passed through a cellulose filter ( $3 \mathrm{hw}$, Sartorius, Göttingen, Germany), and stored at $-18{ }^{\circ} \mathrm{C}$. The $\mathrm{NH}_{4}{ }^{+}$and $\mathrm{NO}_{3}{ }^{-}$concentrations in the filtrate were measured photometrically with a $\mathrm{SAN}^{++}$continuous flow injection analyzer (Skalar Analytical B.V., The Netherlands). $\mathrm{NO}_{3}{ }^{-}$concentrations were measured using the copper-cadmium reduction method (Skalar method 461-000), the $\mathrm{NH}_{4}^{+}$concentrations with the Berthelot reaction method (Skalar method 155-000). Daily rates of net ammonification and net nitrification (unit: $\mathrm{mg} \mathrm{N} \mathrm{kg}{ }^{-1}$ dry soil day ${ }^{-1}$ ) were calculated as the difference of the $\mathrm{NO}_{3}{ }^{-}-\mathrm{N}$ or $\mathrm{NH}_{4}{ }^{+}-\mathrm{N}$ concentrations at the beginning and the end of the incubation period $\left(\mathrm{t}_{1}-\mathrm{t}_{0}\right)$, divided by the days of field incubation. The sum of net ammonification and net nitrification rate was termed daily net $\mathrm{N}$ mineralization rate.

\subsection{Characterization of soil properties}

For characterizing soil physical and chemical properties, additional soil samples were taken at four depths $(0-10 ; 10-20$; 20-40; and 40-60 cm) from the centre of each plot. Total concentrations of $\mathrm{C}$ and $\mathrm{N}$ were measured with a $\mathrm{C} / \mathrm{N}$ analyzer (Vario EL III, Elementar, Hanau, Germany) after the samples had been dried $\left(70{ }^{\circ} \mathrm{C}, 48 \mathrm{~h}\right.$ ), sieved (fraction $<2 \mathrm{~mm}$ ), and milled. The effective cation exchange capacity was determined by percolating $2.5 \mathrm{~g}$ fresh soil material with $100 \mathrm{ml} 0.2 \mathrm{~N} \mathrm{BaCl}_{2}$ solution that was subsequently analyzed using ICP-OES (Optima 5300 DV, Perkin Elmer, Waltham, Massachusetts, USA). Base saturation was calculated as the percentage of $\mathrm{Ca}, \mathrm{K}, \mathrm{Mg}$, and $\mathrm{Na}$ ions in the effective cation exchange capacity. The soil $\mathrm{pH}\left(\mathrm{H}_{2} \mathrm{O}\right)$ and $\mathrm{pH}(\mathrm{KCl})(1 \mathrm{~N} \mathrm{KCl})$ values were measured with an InLab 413 glass electrode (Mettler-Toledo, Greifensee, Switzerland) in saturated soil suspensions consisting of $10 \mathrm{~g}$ fresh fine soil (mineral soil), or $5 \mathrm{~g}$ of the organic layer, in $25 \mathrm{ml}$ demineralized water. Soil bulk density and the water content of the soil were determined by the difference of fresh and dry weight after drying at $105^{\circ} \mathrm{C}$ for $48 \mathrm{~h}$. Particle size distribution and the relative abundance of different fractions were analyzed by sedimentation. Canopy closure was measured by hemispherical photography (Coolprix 8400, Fisheye converter UR-E16; Nikon, Tokio, Japan).

\subsection{Statistical analyses}

Arithmetic means and standard errors are presented throughout the paper. Statistical analyses were carried out using R software (version 2.10.1). All data sets were tested for normal distribution with the Shapiro-Wilk test and with Levene's test for homogeneity of variances. Since the data on $\mathrm{N}$ conversion rates, $\mathrm{C} / \mathrm{N}$ ratio, and $\mathrm{N}$ stocks were not normally distributed, we tested for significance of differences between the five different forest development stages using the Kruskal-Wallis rank sum test combined with the two-sample Mann-Whitney $U$-test (with Bonferroni-correction and a corrected level of significance of $P \leq 0.005$ ) for subsequent pairwise comparisons for cases where the Kruskal-Wallis rank sum test showed significant differences. To test for significant differences between the forest development stages in the normally distributed parameters $\mathrm{pH}$ and base saturation, we used one-way analysis of variance (ANOVA) with a significance level of $P \leq$ 0.05 . Pearson correlation coefficients were calculated for analyzing the relationship between total $\mathrm{N}, \mathrm{pH}$, and net $\mathrm{N}$ mineralization rate. Multiple regression analysis was calculated with SAS software (version 9.1) with stepwise forward variable selection to investigate the influence of the soil chemical parameters on the net $\mathrm{N}$ mineralization rate in the two different soil depths.

\section{Results}

\subsection{Soil chemical characteristics}

All plots were characterized by high soil acidity, with the $\mathrm{pH}$ ranging from 3.6 to 4.0 (in $\mathrm{H}_{2} \mathrm{O}$ ) and 3.0 to 3.6 (in $\mathrm{KCl}$ ) (Table 3). Soil texture was dominated by sand and silt (51\% sand, $36 \%$ silt, and $13 \%$ clay), and the mean soil depth to the bedrock was $54 \pm 1 \mathrm{~cm}$ (data not shown). The mean depth of the organic layer $(20 \pm 2 \mathrm{~cm})$ exhibited a statistically insignificant trend $(P=0.47)$ for higher values in the optimum stage (C) and lower values in the regeneration (A) and the decay (E) stages than in the initial (B) and over-mature (D) stages (Table 3). Total $\mathrm{N}$ content, $\mathrm{C} / \mathrm{N}$ ratio, $\mathrm{pH}$ value, and base saturation in the upper soil profile did not differ between the five forest development stages (Table 3). Canopy closure was significantly lower in the decay (E) stage (74 \%) than in the initial (B), optimum (C), and over-mature (D) stages (85$91 \%)$. The soil water content in summer and autumn was highest in the uppermost soil layer $(0-10 \mathrm{~cm})$ and decreased with soil depth. At $0-10 \mathrm{~cm}$, a (statistically insignificant) trend for lower soil water content in the optimum (C) and overmature (D) stages than in the other development stages existed; in the 10-20 cm horizon, the soil contained more water in the optimum (C) than in the regeneration (A) stage.

\subsection{Net $\mathrm{N}$ mineralization rate}

The concentration of $\mathrm{NH}_{4}{ }^{+}$in the topsoil $\left(0-10 \mathrm{~cm} ; \mathrm{K}_{2} \mathrm{SO}_{4}\right.$ extraction) ranged between 20 and $70 \mathrm{mg} \mathrm{N} \mathrm{kg}^{-1}$ dry soil in the four measuring periods; it was much lower at $10-20 \mathrm{~cm}$ (Table 4: $\mathrm{t}_{0}$ figures). The $\mathrm{NO}_{3}{ }^{-}$concentration was 2 to 10 
Table 3 Soil chemical and physical characteristics at two soil depths $(0-10 ; 10-20 \mathrm{~cm})$ of the topsoil together with canopy closure in the five forest development stages $(\mathrm{A}$, regeneration; $\mathrm{B}$, initial; $\mathrm{C}$, optimum; $\mathrm{D}$, overmature; E, decay stage)
Means $( \pm \mathrm{SE})$ followed by the same letter within a row do not differ significantly $(P \leq 0.05$, [Kruskal-Wallis rank sum test for $\mathrm{N}_{\mathrm{t}}, \mathrm{C} / \mathrm{N}$ ratio, water content and canopy cover; ANOVA for $\mathrm{pH}$ and base saturation])

$N=5$ plots per stage

\begin{tabular}{|c|c|c|c|c|c|}
\hline & A & $\mathrm{B}$ & $\mathrm{C}$ & $\mathrm{D}$ & $\mathrm{E}$ \\
\hline $\begin{array}{l}\text { Depth of organic } \\
\text { layer }[\mathrm{cm}]\end{array}$ & $16.8 \pm 3.7 \mathrm{a}$ & $19.4 \pm 6.8 \mathrm{a}$ & $25.2 \pm 2.4 \mathrm{a}$ & $20.0 \pm 1.3 \mathrm{a}$ & $17.4 \pm 2.6 \mathrm{a}$ \\
\hline \multicolumn{6}{|l|}{$0-10 \mathrm{~cm}$} \\
\hline $\mathrm{pH}\left(\mathrm{H}_{2} \mathrm{O}\right)$ & $3.7 \pm 0.0 \mathrm{a}$ & $3.8 \pm 0.2 \mathrm{a}$ & $3.7 \pm 0.1 \mathrm{a}$ & $3.6 \pm 0.1 \mathrm{a}$ & $3.8 \pm 0.1 \mathrm{a}$ \\
\hline $\mathrm{pH}(\mathrm{KCl})$ & $3.2 \pm 0.1 \mathrm{a}$ & $3.3 \pm 0.2 \mathrm{a}$ & $3.2 \pm 0.1 \mathrm{a}$ & $3.0 \pm 0.1 \mathrm{a}$ & $3.2 \pm 0.1 \mathrm{a}$ \\
\hline $\mathrm{N}_{\mathrm{t}}\left[\mathrm{kg} \mathrm{ha}^{-1}\right]$ & $4,273 \pm 365 a$ & $5,033 \pm 110 \mathrm{a}$ & $3,744 \pm 627 \mathrm{a}$ & $3,996 \pm 657 \mathrm{a}$ & $4,802 \pm 189 \mathrm{a}$ \\
\hline $\mathrm{C} / \mathrm{N}$ ratio & $19.9 \pm 0.6 \mathrm{a}$ & $19.8 \pm 1.0 \mathrm{a}$ & $23.6 \pm 3.8 \mathrm{a}$ & $21.0 \pm 1.5 \mathrm{a}$ & $20.0 \pm 0.9 \mathrm{a}$ \\
\hline Base saturation [\%] & $12.3 \pm 4.0 \mathrm{a}$ & $11.1 \pm 3.9 \mathrm{a}$ & $11.9 \pm 4.7 \mathrm{a}$ & $13.4 \pm 4.8 \mathrm{a}$ & $11.1 \pm 2.9 \mathrm{a}$ \\
\hline Water content [\%] & $74.0 \pm 2.2 \mathrm{a}$ & $71.1 \pm 1.7 \mathrm{a}$ & $67.5 \pm 3.9 \mathrm{a}$ & $67.4 \pm 2.6 \mathrm{a}$ & $74.9 \pm 0.9 \mathrm{a}$ \\
\hline \multicolumn{6}{|l|}{$10-20 \mathrm{~cm}$} \\
\hline $\mathrm{pH}\left(\mathrm{H}_{2} \mathrm{O}\right)$ & $4.0 \pm 0.1 \mathrm{a}$ & $3.9 \pm 0.3 \mathrm{a}$ & $3.9 \pm 0.0 \mathrm{a}$ & $3.7 \pm 0.1 \mathrm{a}$ & $3.8 \pm 0.1 \mathrm{a}$ \\
\hline $\mathrm{pH}(\mathrm{KCl})$ & $3.6 \pm 0.1 \mathrm{a}$ & $3.5 \pm 0.2 \mathrm{a}$ & $3.4 \pm 0.1 \mathrm{a}$ & $3.3 \pm 0.2 \mathrm{a}$ & $3.4 \pm 0.1 \mathrm{a}$ \\
\hline $\mathrm{N}_{\mathrm{t}}\left[\mathrm{kg} \mathrm{ha}^{-1}\right]$ & $3,339 \pm 1,491 \mathrm{a}$ & $6,807 \pm 2,451 \mathrm{a}$ & $5,209 \pm 1,599 \mathrm{a}$ & $3,135 \pm 646 a$ & $5,019 \pm 2,183 \mathrm{a}$ \\
\hline $\mathrm{C} / \mathrm{N}$ ratio & $19.1 \pm 1.7 \mathrm{a}$ & $20.7 \pm 2.4 \mathrm{a}$ & $19.5 \pm 0.7 \mathrm{a}$ & $17.7 \pm 0.9 \mathrm{a}$ & $18.1 \pm 1.4 \mathrm{a}$ \\
\hline Base saturation [\%] & $6.6 \pm 2.4 \mathrm{a}$ & $7.1 \pm 2.3 \mathrm{a}$ & $5.5 \pm 1.6 \mathrm{a}$ & $5.3 \pm 1.3 \mathrm{a}$ & $4.4 \pm 0.6 \mathrm{a}$ \\
\hline Water content [\%] & $33.7 \pm 4.9 \mathrm{a}$ & $48.1 \pm 5.3 \mathrm{ab}$ & $53.0 \pm 4.4 \mathrm{~b}$ & $36.1 \pm 3.9 \mathrm{ab}$ & $45.3 \pm 4.9 \mathrm{ab}$ \\
\hline Canopy closure [\%] & $81.5 \pm 3.6 \mathrm{ab}$ & $90.5 \pm 2.1 \mathrm{a}$ & $90.0 \pm 0.7 \mathrm{a}$ & $85.4 \pm 1.5 \mathrm{a}$ & $74.3 \pm 2.4 \mathrm{~b}$ \\
\hline
\end{tabular}

times smaller than the $\mathrm{NH}_{4}{ }^{+}$concentration with values in the range between 0 (not detectable) to $10 \mathrm{mg} \mathrm{N} \mathrm{kg}^{-1}$ in the topsoil. The spatial and temporal variations tended to be higher for $\mathrm{NO}_{3}{ }^{-}$than for $\mathrm{NH}_{4}{ }^{+}$with peak $\mathrm{NO}_{3}{ }^{-}$concentrations observed in summer 2010 (up to $38 \mathrm{mg} \mathrm{N} \mathrm{kg}^{-1}$ ).

In the topsoil $(0-10 \mathrm{~cm})$, net $\mathrm{N}$ mineralization rate showed a consistent trend for higher values in the optimum and overmature stages with high canopy closure (stages $\mathrm{C}-\mathrm{D}$ ) compared to the more open development stages, especially the decay stage (E) (Fig. 1). These trends were statistically significant for the $0-10 \mathrm{~cm}$ layer, but persisted only partly at 10 $20 \mathrm{~cm}$ depth. In all four measuring periods, the optimum (C) and over-mature (D) stages showed the highest $\mathrm{N}$ supply rates of all stages. Net $\mathrm{N}$ mineralization was significantly lower in 2009 than in $2010(P \leq 0.01$; except for the $10-20 \mathrm{~cm}$ layer in autumn; data not shown), but with a similar pattern among the five forest development stages and was significantly higher in summer than in autumn $(P \leq 0.01$; data not shown). At 0 $10 \mathrm{~cm}$ depth, nitrification rate was very low and $\mathrm{N}$ mineralization rate thus largely equalled ammonification rate (Fig. 1). At $10-20 \mathrm{~cm}$ depth, the relative importance of nitrification was higher and more than $60 \%$ of the $\mathrm{NH}_{4}{ }^{+}$released by mineralization in summer was oxidized to $\mathrm{NO}_{3}{ }^{-}$; nitrification accounted for $35 \%$ of net $\mathrm{N}$ mineralization in autumn. However, the absolute rates of ammonification and nitrification were about ten times smaller at $10-20 \mathrm{~cm}$ depth than at 0 $10 \mathrm{~cm}$ (Fig. 1). Multiple regression analysis showed that $\mathrm{pH}$ $(\mathrm{KCl})$ had a significant $(P \leq 0.05)$ and total $\mathrm{N}$ a marginally significant influence $(P=0.07)$ on net $\mathrm{N}$ mineralization rate at 0-10 cm soil depth (Table 5). At 10-20 cm depth, we found significant effects of the $\mathrm{C} / \mathrm{N}$ ratio $(P \leq 0.01)$ and base saturation $(P \leq 0.05)$ on net $\mathrm{N}$ mineralization rate.

\section{Discussion}

In the studied old-growth spruce forest, net $\mathrm{N}$ mineralization rate was significantly higher in the optimum and over-mature stages $(C, D)$ with highest canopy closure than in the more open decay stage. $\mathrm{N}$ supply also tended to be lower in the early (A and B) than the optimum and over-mature stages (difference only partly significant). This result does not confirm our first hypothesis that net $\mathrm{N}$ mineralization increases with proceeding forest development resulting in highest mineralization rates in the open decay stage, as is implied by some earlier work on $\mathrm{N}$ mineralization comparing gaps with the forest interior (Prescott et al. 1992; Scharenbroch and Brockheim 2007; Bagherzadeh et al. 2008). Elevated N mineralization rates in gaps as compared to the forest interior have been explained in lowland spruce forests with more favorable microclimatic conditions, i.e., higher solar radiation and higher temperatures, and also higher soil moisture (Scharenbroch and Brockheim 2007). In the mountain spruce forest on Mt. Brocken, the cold and wet environment with approximately 5 months of snow cover, high annual precipitation, and low temperatures even in summer (Glässer 1994) creates very moist and acidic soil conditions, which may hamper soil biological activity and the breakdown of organic material. Development stages with a warmer soil in summer and partial drying of the very wet soil, which would be more favorable for decomposer activity, are virtually absent from the studied high elevation forest where canopy cover remains fairly high (74\%) even in the decay stage due to the abundance of standing dead spruce trees. In this moist environment, partial soil drying through canopy transpiration by mature spruce trees might be more important for decomposer activity than 
Table 4 Initial concentrations of $\mathrm{NO}_{3}{ }^{-}$and $\mathrm{NH}_{4}{ }^{+}$in the cylinders $\left(\mathrm{t}_{0}\right)$ and at the end of the incubation period $\left(\mathrm{t}_{1}\right)$ in the each two seasons in 2009 and 2010 at two soil depths $(0-10 \mathrm{~cm} ; 10-20 \mathrm{~cm})$ in the five development stages (A, regeneration; B, initial; C, optimum; D, over-mature; E, decay)

\begin{tabular}{|c|c|c|c|c|c|c|c|c|}
\hline & & & A & $\mathrm{B}$ & $\mathrm{C}$ & $\mathrm{D}$ & $\mathrm{E}$ & $P$ value \\
\hline \multicolumn{9}{|c|}{$\mathbf{N O}_{3}^{-}\left(\mathrm{mg} \mathrm{N} \mathrm{kg}^{-1}\right)$} \\
\hline \multirow[t]{6}{*}{ Summer 2009} & $0-10 \mathrm{~cm}$ & & & & & & & \\
\hline & & $\mathrm{t}_{0}$ & $1.5 \pm 0.8$ & $3.1 \pm 1.8$ & $1.5 \pm 0.6$ & $0.9 \pm 0.5$ & $4.2 \pm 0.8$ & $*$ \\
\hline & & $t_{1}$ & $5.2 \pm 5.3$ & $15.3 \pm 8.1$ & $11.7 \pm 2.3$ & $27.0 \pm 4.6$ & $31.7 \pm 5.3$ & $* *$ \\
\hline & $10-20 \mathrm{~cm}$ & & & & & & & \\
\hline & & $t_{0}$ & $0.8 \pm 0.1$ & $1.3 \pm 0.5$ & $1.6 \pm 0.3$ & $1.1 \pm 0.2$ & $2.4 \pm 0.6$ & $*$ \\
\hline & & $t_{1}$ & $6.0 \pm 1.8$ & $6.8 \pm 2.2$ & $8.9 \pm 1.1$ & $13.1 \pm 1.8$ & $14.2 \pm 2.9$ & $*$ \\
\hline \multirow[t]{6}{*}{ Autumn 2009} & $0-10 \mathrm{~cm}$ & & & & & & & \\
\hline & & $t_{0}$ & 0 & 0 & 0 & 0 & $2.0 \pm 1.9$ & \\
\hline & & $t_{1}$ & 0 & 0 & $0.1 \pm 1.1$ & 0 & 0 & \\
\hline & $10-20 \mathrm{~cm}$ & & & & & & & \\
\hline & & $t_{0}$ & $1.1 \pm 0.5$ & $2.1 \pm 0.8$ & $0.4 \pm 0.4$ & $0.8 \pm 0.4$ & $2.8 \pm 0.9$ & \\
\hline & & $t_{1}$ & $4.5 \pm 1.2$ & $6.1 \pm 1.1$ & $3.1 \pm 0.9$ & $6.2 \pm 1.0$ & $6.4 \pm 1.2$ & $*$ \\
\hline \multirow[t]{6}{*}{ Summer 2010} & $0-10 \mathrm{~cm}$ & & & & & & & \\
\hline & & $t_{0}$ & $3.3 \pm 6.3$ & $38.0 \pm 26.4$ & $21.4 \pm 25.2$ & $25.2 \pm 21.0$ & $26.4 \pm 23.3$ & \\
\hline & & $t_{1}$ & $31.8 \pm 10.3$ & $33.0 \pm 8.6$ & $31.4 \pm 10.1$ & $36.5 \pm 16.4$ & $58.1 \pm 12.4$ & \\
\hline & $10-20 \mathrm{~cm}$ & & & & & & & \\
\hline & & $t_{0}$ & $0.7 \pm 1.7$ & $10.9 \pm 7.8$ & $3.8 \pm 5.1$ & $1.7 \pm 3.8$ & $6.9 \pm 4.7$ & \\
\hline & & $t_{1}$ & $13.7 \pm 4.9$ & $19.3 \pm 5.3$ & $23.7 \pm 2.8$ & $18.5 \pm 5.4$ & $36.7 \pm 4.6$ & $*$ \\
\hline \multirow[t]{6}{*}{ Autumn 2010} & $0-10 \mathrm{~cm}$ & & & & & & & \\
\hline & & $t_{0}$ & 0 & 0 & 0 & 0 & 0 & \\
\hline & & $t_{1}$ & $16.0 \pm 9.3$ & $11.2 \pm 6.3$ & $9.8 \pm 6.7$ & $13.8 \pm 5.6$ & $18.3 \pm 6.8$ & \\
\hline & $10-20 \mathrm{~cm}$ & & & & & & & \\
\hline & & $t_{0}$ & 0 & 0 & 0 & 0 & 0 & \\
\hline & & $\mathrm{t}_{1}$ & $5.2 \pm 3.1$ & $3.5 \pm 2.8$ & $2.1 \pm 1.7$ & $4.2 \pm 2.3$ & $6.1 \pm 2.3$ & \\
\hline \multicolumn{9}{|l|}{$\mathbf{N H}_{\mathbf{4}}^{+}\left(\mathrm{mg} \mathrm{N} \mathrm{kg}^{-1}\right)$} \\
\hline \multirow[t]{6}{*}{ Summer 2009} & $0-10 \mathrm{~cm}$ & & & & & & & \\
\hline & & $\mathrm{t}_{0}$ & $52.0 \pm 4.8$ & $62.1 \pm 6.1$ & $65.2 \pm 6.0$ & $61.8 \pm 5.5$ & $70.1 \pm 16.5$ & \\
\hline & & $t_{1}$ & $156.3 \pm 28.9$ & $114.9 \pm 18.3$ & $192.1 \pm 15.1$ & $182.3 \pm 22.2$ & $77.9 \pm 10.5$ & $* * *$ \\
\hline & $10-20 \mathrm{~cm}$ & & & & & & & \\
\hline & & $\mathrm{t}_{0}$ & $10.6 \pm 1.4$ & $13.3 \pm 1.2$ & $14.3 \pm 1.2$ & $13.1 \pm 1.0$ & $10.3 \pm 0.67$ & $* * *$ \\
\hline & & $t_{1}$ & $35.0 \pm 17.2$ & $12.5 \pm 1.4$ & $17.3 \pm 2.8$ & $15.9 \pm 2.0$ & $7.4 \pm 0.78$ & $* * *$ \\
\hline \multirow[t]{6}{*}{ Autumn 2009} & $0-10 \mathrm{~cm}$ & & & & & & & \\
\hline & & $\mathrm{t}_{0}$ & $52.7 \pm 7.1$ & $69.3 \pm 12.1$ & $68.2 \pm 7.7$ & $58.7 \pm 4.2$ & $55.7 \pm 6.4$ & \\
\hline & & $t_{1}$ & $107.9 \pm 22.7$ & $86.6 \pm 7.5$ & $164.5 \pm 33.4$ & $161.8 \pm 22.2$ & $91.6 \pm 25.3$ & $* * *$ \\
\hline & $10-20 \mathrm{~cm}$ & & & & & & & \\
\hline & & $\mathrm{t}_{0}$ & $6.4 \pm 0.9$ & $7.8 \pm 0.5$ & $11.6 \pm 3.1$ & $8.4 \pm 0.7$ & $6.9 \pm 0.5$ & $* * *$ \\
\hline & & $\mathrm{t}_{1}$ & $15.8 \pm 3.9$ & $10.7 \pm 1.1$ & $21.8 \pm 5.0$ & $19.6 \pm 2.6$ & $9.5 \pm 1.9$ & $* * *$ \\
\hline \multirow[t]{6}{*}{ Summer 2010} & $0-10 \mathrm{~cm}$ & & & & & & & \\
\hline & & $\mathrm{t}_{0}$ & $40.5 \pm 13.5$ & $59.2 \pm 5.6$ & $64.8 \pm 11.0$ & $53.2 \pm 5.7$ & $34.2 \pm 4.5$ & \\
\hline & & $t_{1}$ & $116.8 \pm 39.7$ & $247.0 \pm 29.9$ & $246.3 \pm 22.2$ & $251.4 \pm 34.3$ & $117.4 \pm 18.2$ & $* *$ \\
\hline & $10-20 \mathrm{~cm}$ & & & & & & & \\
\hline & & $t_{0}$ & $5.9 \pm 1.1$ & $6.8 \pm 0.56$ & $5.4 \pm 0.62$ & $6.8 \pm 0.97$ & $9.6 \pm 3.0$ & \\
\hline & & $t_{1}$ & $9.9 \pm 1.1$ & $14.6 \pm 3.3$ & $15.9 \pm 3.4$ & $16.6 \pm 1.9$ & $14.0 \pm 3.9$ & \\
\hline \multirow[t]{6}{*}{ Autumn 2010} & $0-10 \mathrm{~cm}$ & & & & & & & \\
\hline & & $\mathrm{t}_{0}$ & $22.2 \pm 2.4$ & $31.8 \pm 3.1$ & $29.3 \pm 4.5$ & $35.9 \pm 6.5$ & $30.5 \pm 9.4$ & \\
\hline & & $t_{1}$ & $100.3 \pm 34.1$ & $176.1 \pm 61.5$ & $189.6 \pm 37.0$ & $146.3 \pm 23.3$ & $53.7 \pm 9.7$ & \\
\hline & $10-20 \mathrm{~cm}$ & & & & & & & \\
\hline & & $t_{0}$ & $5.7 \pm 0.7$ & $5.9 \pm 0.4$ & $6.4 \pm 0.4$ & $8.8 \pm 1.8$ & $8.2 \pm 2.2$ & \\
\hline & & $t_{1}$ & $9.6 \pm 2.1$ & $16.1 \pm 2.4$ & $29.6 \pm 10.5$ & $12.6 \pm 1.7$ & $8.3 \pm 0.8$ & \\
\hline
\end{tabular}

Given are means $( \pm$ SE). Significant differences between the means in a row are marked with asterisks $(* P \leq 0.05 ; * * P \leq 0.01 ; * * * P \leq 0.001 ;$ KruskalWallis rank sum test; $N=5$ )

0 stands for 'not detectable' 


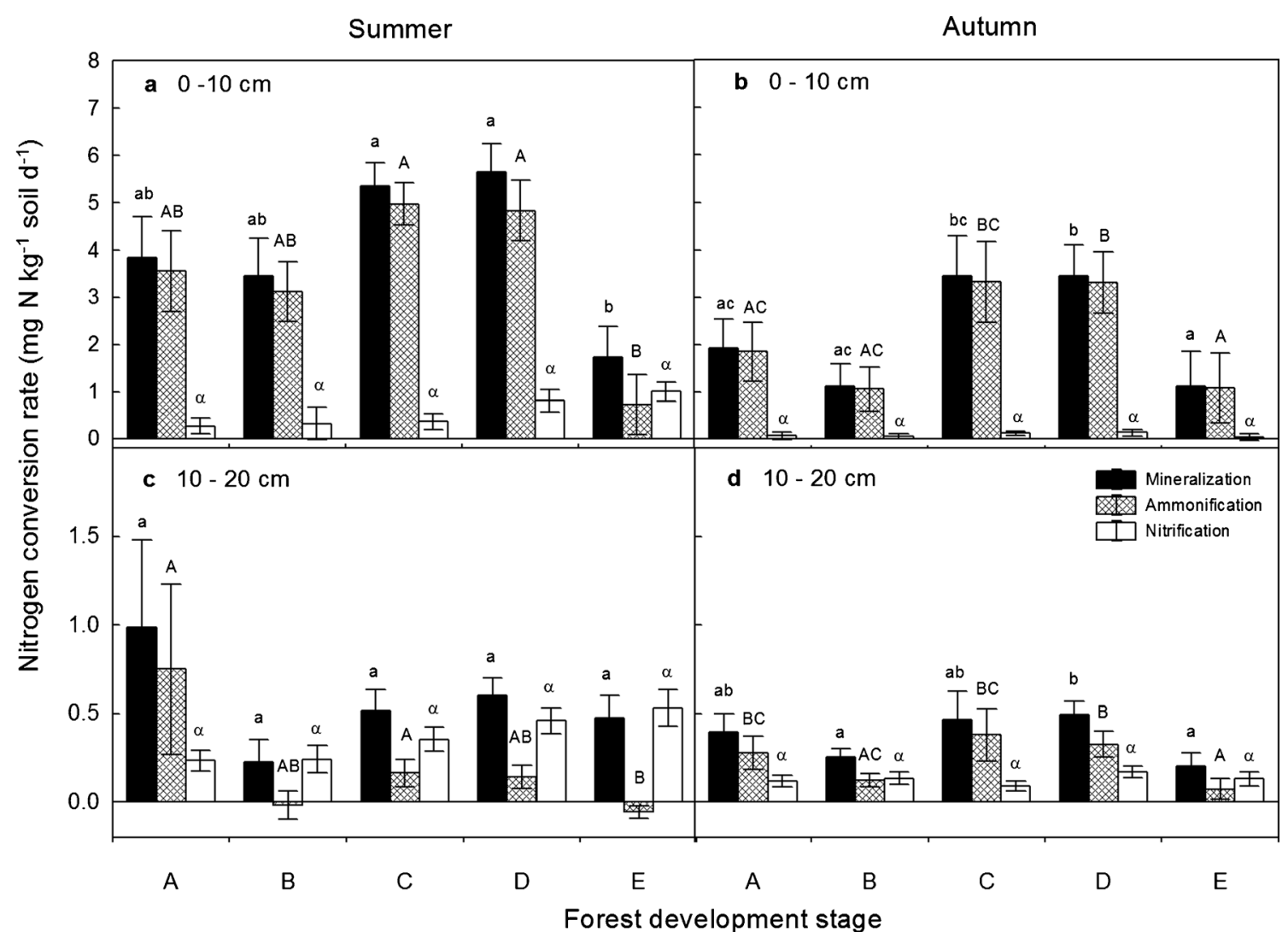

Fig. $1 \mathrm{~N}$ conversion rates at two soil depths $(\mathbf{a}, \mathbf{b}=0-10 \mathrm{~cm} ; \mathbf{c}, \mathbf{d}=10$ $20 \mathrm{~cm}$ ) of the topsoil in the five forest development stages (A, regeneration; B, initial; C, optimum; D, over-mature; E, decay stage) of both sampling years (2009 and 2010); error bars represent the standard error

increased light transmission to the ground and soil warming on sunny days in gaps.

The atmospheric $\mathrm{N}$ deposition in the study area is another factor that could explain higher $\mathrm{N}$ mineralization rates in dense coniferous stands than in the more open forest stages. In the study area, measured deposition rates ranged between $27 \mathrm{~kg} \mathrm{~N} \mathrm{ha}^{-1}$ year $^{-1}$ in open areas and $47 \mathrm{~kg} \mathrm{~N} \mathrm{ha}^{-1}$ year $^{-1}$ in closed forest stands where deposition is increased due to canopy interception (Böhlmann et al. 2005). These deposition rates clearly exceed the critical loads of $10-20 \mathrm{~kg} \mathrm{~N} \mathrm{ha}^{-1}$ year $^{-1}$, which has been assumed for boreal and temperate coniferous forests (Achermann and Bobbink 2003). Several studies found increased $\mathrm{N}$ mineralization rates in areas with elevated $\mathrm{N}$ deposition (e.g., Peréz et al. 1998; Rowe et al. 2012), which were

Table 5 Results of multiple regression analyses for soil chemical parameters predicting net $\mathrm{N}$ mineralization rate

\begin{tabular}{clll}
\hline & Predictor & $F$ value & $P$ value \\
\hline $\mathrm{N}$ mineralization rate: $0-10 \mathrm{~cm}$ & $\mathrm{pH}(\mathrm{KCl})$ & 7.44 & 0.01 \\
$\left(\mathrm{R}^{2}=0.33 ; P=0.02\right)$ & Total N & 3.58 & 0.07 \\
$\mathrm{~N}$ mineralization rate: $10-20 \mathrm{~cm}$ & $\mathrm{C} / \mathrm{N}$ & 9.32 & 0.007 \\
$\left(\mathrm{R}^{2}=0.39 ; P=0.03\right)$ & Base saturation & 6.36 & 0.02 \\
\hline
\end{tabular}

of the mean, small Latin letters indicate significant differences between $\mathrm{N}$ mineralization rate, capital letters between the ammonification rates, and Greek letters between the nitrification rates; $N=5(P \leq 0.05$, KruskalWallis rank sum test)

probably caused by shifts in the composition of the soil microbial community (Zechmeister-Boltenstern et al. 2011). In general, saprophytic fungi are dominating over bacteria in the decomposer community of acidic soils due to the generally higher acid tolerance of the former (Rousk et al. 2009). However, Lauber et al. (2008) showed that the abundance of fungal taxa was more strongly related to the $\mathrm{C} / \mathrm{N}$ ratio and the total $\mathrm{P}$ content of the soil than to soil $\mathrm{pH}$ itself. At our study sites with $\mathrm{pH}(\mathrm{KCl})$ values below 3.3 , it is likely that both ammonification and nitrification are mainly conducted by acid-tolerant fungi. Nevertheless, our correlation analysis showed that $\mathrm{N}$ mineralization rate was in both soil horizons mainly dependent on $\mathrm{pH}$, base saturation and the $\mathrm{C} / \mathrm{N}$ ratio assuming that even small changes in soil $\mathrm{pH}$ and $\mathrm{C} / \mathrm{N}$ ratio may influence net $\mathrm{N}$ mineralization rate at this site.

Besides the control by abiotic factors, $\mathrm{N}$ mineralization should vary across the forest development stages with changing litter supply and possibly also with variation in plant $\mathrm{N}$ demand. Spruce needles are relatively poor in N, but rich in lignin causing thus slower leaf litter decomposition than in most broad-leaved trees and herbaceous understory plants. Nevertheless, input of fresh spruce needles might be an influential factor for $\mathrm{N}$ mineralization in the studied forest, because the assumed variation in needle litter input matches with 
measured $\mathrm{N}$ mineralization rates across the forest development cycle. The lower net $\mathrm{N}$ mineralization rate in the decay stage could be due to reduced input of fresh organic material, mainly spruce needles, and a resulting shortage of organic $\mathrm{C}$ and $\mathrm{N}$. Variation in herb litter supply is an unlikely explanation because the herb and cryptogam layers did not differ significantly in their structure between the forest development stages (Dittrich et al. 2013).

Deadwood was probably not a major $\mathrm{N}$ source in the open (late and early) forest development stages of our study site. Deadwood in the early stages of decay has been shown to act as a transient $\mathrm{N}$ sink, rather than a source as one might intuitively expect, since $\mathrm{N}$ is immobilized by woodinhabiting fungi (Boddy and Watkinson 1995; Herrmann and Prescott 2008). Even over the entire span from tree death to complete wood decomposition, the contribution of deadwood decay to the $\mathrm{N}$ supply of the vegetation is low given the low decomposition rates in cold coniferous forests (Harmon 2009). Accordingly, Hart (1999) estimated that the net $\mathrm{N}$ release from decaying deadwood contributed only by about 4-6\% to the estimated plant $\mathrm{N}$ demand in an old-growth conifer forest of the Pacific Northwest of North America.

A likely higher fine root abundance of Picea abies in the optimum and over-mature stages as compared to the decay stage might also contribute to the lowered $\mathrm{N}$ mineralization rate in the latter stage, as Colin-Belgrand et al. (2003) found higher net $\mathrm{N}$ mineralization in the rhizosphere of $P$. abies than in soil with lower root density. These authors assumed that this effect was caused by differences in the quality of the available carbon in rhizosphere and non-rhizosphere soil.

The rapid decrease in $\mathrm{N}$ mineralization rate with soil depth is likely to result primarily from lowered temperature (and perhaps decreased base saturation), since $\mathrm{C} / \mathrm{N}$ ratio and soil moisture were generally more favorable at 10-20 than 0$10 \mathrm{~cm}$ depth. Sajedi et al. (2012) could also show that the soil oxygen level is a restricting factor for biological processes and thus the availability of $\mathrm{N}$ in old-growth forests, which could be an explanation of the decreased $\mathrm{N}$ mineralization with soil depth also in our case. Similarly, other authors found more than $75 \%$ of net $\mathrm{N}$ mineralization in temperate acid forest soils to occur in the uppermost $0-10 \mathrm{~cm}$ layer (e.g., Persson and Wirén 1995).

The figures of net $\mathrm{N}$ mineralization rate obtained from the field incubation in the montane spruce forest studied by us $\left(0.23-0.91 \mathrm{~kg} \mathrm{~N} \mathrm{ha}^{-1} \mathrm{day}^{-1}\right)$ fit rather well with literature data of net $\mathrm{N}$ mineralization in other European spruce stands $(0.33$, Jussy et al. 2004; 0.36, Šantrůčková et al. 2009; and 0.10$0.29 \mathrm{~kg} \mathrm{~N} \mathrm{ha}^{-1} \mathrm{day}^{-1}$, Persson and Wirén 1995); however, they are in the upper range of reported values. We suggest that the relatively high measured $\mathrm{N}$ mineralization rates may result from the rather high $\mathrm{N}$ deposition on Mt. Brocken.

Our data may even underestimate the production of $\mathrm{NO}_{3}{ }^{-}$, since the cylinders allowed water percolation during the incubation period and thus the leaching of highly mobile $\mathrm{NO}_{3}{ }^{-}$ions in periods of high rainfall. Thus, local differences in the amount of throughfall and percolating water in this structurally heterogeneous forest may have influenced the measured $\mathrm{NO}_{3}{ }^{-}$concentrations in the soil cylinders to a certain extent. This could be one explanation of the rather high spatial variation found in the actual $\mathrm{NO}_{3}{ }^{-}$concentrations in the cylinders across the plots and in apparent net nitrification rates. In the absence of important $\mathrm{NO}_{3}{ }^{-}$-preferring species in this ecosystem, $\mathrm{NO}_{3}{ }^{-}$could also be subjected to frequent leaching in the soil outside the incubation cylinders when rainfall is high. Norway spruce, the only abundant tree species in our plots, and Calamagrostis villosa, one of the most abundant grass species in the understory, are known to prefer $\mathrm{NH}_{4}{ }^{+}$over $\mathrm{NO}_{3}{ }^{-}$as mineral $\mathrm{N}$ source (Ellenberg and Leuschner 2010). This adaptation fits to the dominance of $\mathrm{NH}_{4}{ }^{+}$over $\mathrm{NO}_{3}{ }^{-}$in the soils on Mt. Brocken.

\section{Conclusions}

$\mathrm{N}$ mineralization markedly differed between the development stages of this old-growth spruce forest, thereby increasing the spatial and temporal heterogeneity of $\mathrm{N}$ availability. In contrast to lowland spruce forests, $\mathrm{N}$ mineralization was lower in the more open patches than in the closed forest patches, which might be attributable to reduced litter supply, lower canopy $\mathrm{N}$ interception, and perhaps less drained soils due to reduced canopy transpiration. Our results demonstrate that the gap dynamics in natural forests have a profound influence on forest biogeochemistry. If it turns out that reduced mineral $\mathrm{N}$ supply in the decay stage of old-growth forests is a characteristic phenomenon, this could be a hint to a biogeochemical feedback at the ecosystem level leading to increased mineral $\mathrm{N}$ supply when plant (tree) demand is high- and downregulation through reduced litter supply when tree uptake is low. Analyses of the spatial and temporal variability of soil microbial activity and additional $\mathrm{N}$ transformation measurements with the ${ }^{15} \mathrm{~N}$ pool dilution technique in this old-growth forest would provide further insights into the effects of the forest development cycle on $\mathrm{N}$ mineralization.

Acknowledgments We are grateful to the Harz National Park administration and to Dr. H.-U. Kison in particular, for granting permissions and manifold support of our work. H. Calvete Sogo assisted during the laboratory analyses; the help is gratefully acknowledged. We thank Prof. Dr. Cindy E. Prescott (Vancouver) and an unknown reviewer for their helpful comments on the manuscript.

Funding This study was funded by the Stemmler Foundation, a member of the Stifterverband für die Deutsche Wissenschaft with a grant to M. Hauck and C. Leuschner. The grant was approved in the framework of the Stifterverband program 'Biodiversity and Ecology in National Parks (BEN)'. 


\section{References}

Aber JD, Goodale CL, Ollinger SV, Smith ML, Magill AH, Martin ME, Hallett RA, Stoddard JL (2003) Is nitrogen deposition altering the nitrogen status of northeastern forests? Bioscience 53:375-389

Achermann B, Bobbink R (2003) Empirical critical loads for nitrogen. Environmental Documentation No. 164. Swiss Agency for the Environment, Forests and Landscape, Berne

Bagherzadeh A, Brumme R, Beese F (2008) Temperature dependence of nitrogen mineralization and microbial status in $\mathrm{O}_{\mathrm{H}}$ horizon of a temperate forest ecosystem. J For Res 19:37-43

Bauhus J, Vor T, Bartsch N, Cowling A (2004) The effects of gaps and liming on forest floor decomposition and soil $\mathrm{C}$ and $\mathrm{N}$ dynamics in a Fagus sylvatica forest. Can J For Res 34:509-518

Boddy L, Watkinson SC (1995) Wood decomposition, higher fungi, and their role in nutrient redistribution. Can J Bot 73:1377-1383

Böhlmann N, Meissner R, Bernsdorf S, Böhme F, Russow R, Wegener U (2005) Studies of atmospheric nitrogen deposition in a mire of the German National Park Hochharz Mountains using two different methods. Water Air Soil Pollut 168:17-32

Colin-Belgrand M, Dambrine E, Bienaimé S, Nys C, Turpault MP (2003) Influence of tree roots on nitrogen mineralization. Can J For Res 18: 260-268

Dittrich S, Hauck M, Jacob M, Rommerskirchen A, Leuschner C (2013) Response of ground vegetation and epiphyte diversity to natural age dynamics in a Central European mountain spruce forest. J Veg Sci 24:675-687

Ellenberg H, Leuschner C (2010) Vegetation Mitteleuropas mit den Alpen in ökologischer, dynamischer und historischer Sicht, 6th edn. Ulmer, Stuttgart

Glässer R (1994) Das Klima des Harzes. Kovač, Hamburg

Harmon ME (2009) Woody detritus mass and its contribution to carbon dynamics of old-growth forests: the temporal context. In: Wirth C et al. (eds) Old-growth forests. Ecological Studies 207. Springer, Berlin, pp 159-190

Hart SC (1999) Nitrogen transformations in fallen tree boles and mineral soil of an old-growth forest. Ecology 80:1385-1394

Hart SC, Nason GE, Myrold DD, Perry DA (1994) Dynamics of gross nitrogen transformations in an old-growth forest: the carbon connection. Ecology 75:880-891

Hauck M, Runge M (2002) Stemflow chemistry and epiphytic lichen diversity in dieback-affected spruce forest of the Harz Mountains, Germany. Flora 197:250-261

Hauck M, Zimmermann J, Jacob M, Dulamsuren C, Bade C, Ahrends B, Leuschner C (2012) Rapid recovery of stem increment in Norway spruce at reduced $\mathrm{SO}_{2}$ levels in the Harz Mountains, Germany. Environ Pollut 164:132-141

Herrmann S, Prescott CE (2008) Mass loss and nutrient dynamics of coarse woody debris in three Rocky Mountain coniferous forests: 21 year results. Can J For Res 38:125-132

IUSS Working Group WRB (2006) World reference base for soil resources 2006 - a framework for international classification, correlation and communication. 2006 edition. World Soil Resources Reports No. 103. FAO, Rome

Jacob M, Bade C, Calvete H, Dittrich S, Leuschner C, Hauck M (2013) Significance of over-mature and decaying trees for carbon stocks in a Central European natural spruce forest. Ecosystems 16:336-346

Jussy JH, Colin-Belgrand M, Dambrine É, Ranger J, Zeller B, Bienaimé $\mathrm{S}$ (2004) $\mathrm{N}$ deposition, $\mathrm{N}$ transformation and $\mathrm{N}$ leaching in acid forest soils. Biogeochemistry 69:241-262

Korpel S̆ (1995) Die Urwälder der Westkarpaten. Gustav Fischer, Stuttgart

Kortzfleisch A (2008) Die Kunst der schwarzen Gesellen, Köhlerei im Harz. Papierflieger, Clausthal-Zellerfeld
Laiho R, Prescott CE (2004) Decay and nutrient dynamics of coarse woody debris in northern coniferous forests: a synthesis. Can J For Res 34:763-777

Lauber CL, Strickland MS, Bradford MA, Fierer N (2008) The influence of soil properties on the structure of bacterial and fungal communities across land-use types. Soil Biol Biochem 40:2407-2415

Lovett GM, Lindberg SE (1993) Atmospheric deposition and canopy interactions of nitrogen in forests. Can J For Res 23:16031616

Peréz CA, Hedin LO, Armesto JJ (1998) Nitrogen mineralization in two unpolluted old-growth forests contrasting biodiversity and dynamics. Ecosystems 1:361-373

Persson T, Wirén A (1995) Nitrogen mineralization and potential nitrification at different soil depths in acid forest soils. Plant Soil 168:5565

Prescott CE (2002) The influence of the forest canopy on nutrient cycling. Tree Physiol 22:1193-1200

Prescott CE, Corbin JP, Parkinson D (1992) Immobilization and availability of $\mathrm{N}$ and $\mathrm{P}$ in forest floors of fertilized Rocky Mountain coniferous forests. Plant Soil 143:1-10

Prescott CE, Hope GD, Blevins LL (2003) Effect of gap size on litter decomposition and soil nitrate concentrations in a high-elevation spruce-fir forest. Can J For Res 33:2210-2220

Rothe A, Mellert KH (2004) Effects of forest management on nitrate concentrations in seepage water of forests in southern Bavaria, Germany. Water Air Soil Pollut 156:337-355

Rousk J, Brookes PC, Bååth E (2009) Contrasting soil pH effects on fungal and bacterial growth suggest functional redundancy in carbon mineralization. Appl Environ Microbiol 75:1589-1596

Rowe EC, Emmett BA, Frogbrook ZL, Robinson DA, Hughes S (2012) Nitrogen deposition and climate effects on soil nitrogen availability: influences of habitat type and soil characteristics. Sci Total Environ 434:62-70

Sajedi T, Prescott CE, Seely B, Lavkulich LM (2012) Relationships among soil moisture, aeration and plant communities in natural and harvested coniferous forests in coastal British Columbia, Canada. J Ecol 100:605-618

Šantrůčková H, Tahovská K, Kopáček J (2009) Nitrogen transformations and pools in N-saturated mountain spruce forest soils. Biol Fertil Soils 45:395-404

Schade R (1926) Der Brocken. Abhandlungen über Geschichte und Natur des Berges. Appelhans, Braunschweig

Scharenbroch BC, Brockheim JG (2007) Impacts of forest gaps on soil properties and processes in old-growth northern hardwood-hemlock forests. Plant Soil 294:219-233

Schmidt MG, Macdonald SE, Rothwell RL (1996) Impacts of harvesting and mechanical site preparation on soil chemical properties of mixed-wood boreal forest sites in Alberta. Can J Soil Sci 76:531540

Spears JHD, Holub SM, Harmon ME, Lajtha K (2003) The influence of decomposing logs on soil biology and nutrient cycling in an oldgrowth mixed coniferous forest in Oregon, U.S.A. Can J For Res 33: 2193-2201

Stöcker G (1997) Struktur und Dynamik der Berg-Fichtenwälder im Hochharz. Ber Naturhist Gesell Hannover 31:31-61

Stöcker G (2002) Growth dynamics of Norway spruce (Picea abies (L.) Karst.) in natural spruce forest ecosystems of the National Park Hochharz - 2. Climax, ageing and decay phases. Forstwiss Centralbl 121:109-127

Vestgarden LS, Nilsen P, Abrahamsen G (2004) Nitrogen cycling in Pinus sylvestris stands exposed to different nitrogen inputs. Scand J For Res 19:38-47

Vitousek PM, Aber JD, Howarth RW, Likens GE, Matson PA, Schindler DW, Schlesinger WH, Tilman DG (1997) Human alteration of the global nitrogen cycle: Sources and consequences. Ecol Appl 7:737-750 
Zanella A, Jabiol B, Ponge JF, Sartori G, De Waal R, Van Delft B, Graefe U, Cools N, Katzensteiner K, Hager H, Englisch M, Brethes A, Broll G, Gobat JM, Brun JJ, Milbert G, Kolb E, Wolf U, Frizzera L, Galvan P, Kolli R, Baritz R, Kemmers R, Vacca A, Serra G, Banas D, Garlato A, Chersich S, Klimo E,
Langohr R (2011) European humus forms reference base. Version 2. HAL:00541496

Zechmeister-Boltenstern S, Michel K, Pfeffer M (2011) Soil microbial community structure in European forests in relation to forest type and atmospheric nitrogen deposition. Plant Soil 343:37-50 